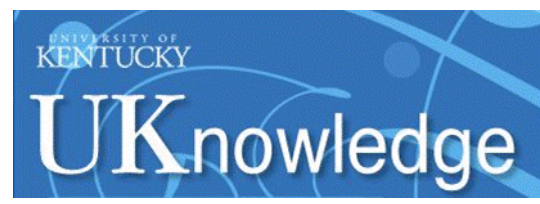

University of Kentucky

UKnowledge

1984

\title{
Two Approaches to Predictive Indeterminacy
}

Gregory Stump

University of Kentucky, gstump@uky.edu

Follow this and additional works at: https://uknowledge.uky.edu/lin_facpub

Part of the Linguistics Commons

Right click to open a feedback form in a new tab to let us know how this document benefits you.

\section{Repository Citation}

Stump, Gregory, "Two Approaches to Predictive Indeterminacy" (1984). Linguistics Faculty Publications.

42.

https://uknowledge.uky.edu/lin_facpub/42

This Article is brought to you for free and open access by the Linguistics at UKnowledge. It has been accepted for inclusion in Linguistics Faculty Publications by an authorized administrator of UKnowledge. For more information, please contact UKnowledge@lsv.uky.edu. 
Two Approaches to Predictive Indeterminacy

Digital Object Identifier (DOI)

10.1515/ling.1984.22.6.811

This article is available at UKnowledge: https://uknowledge.uky.edu/lin_facpub/42 


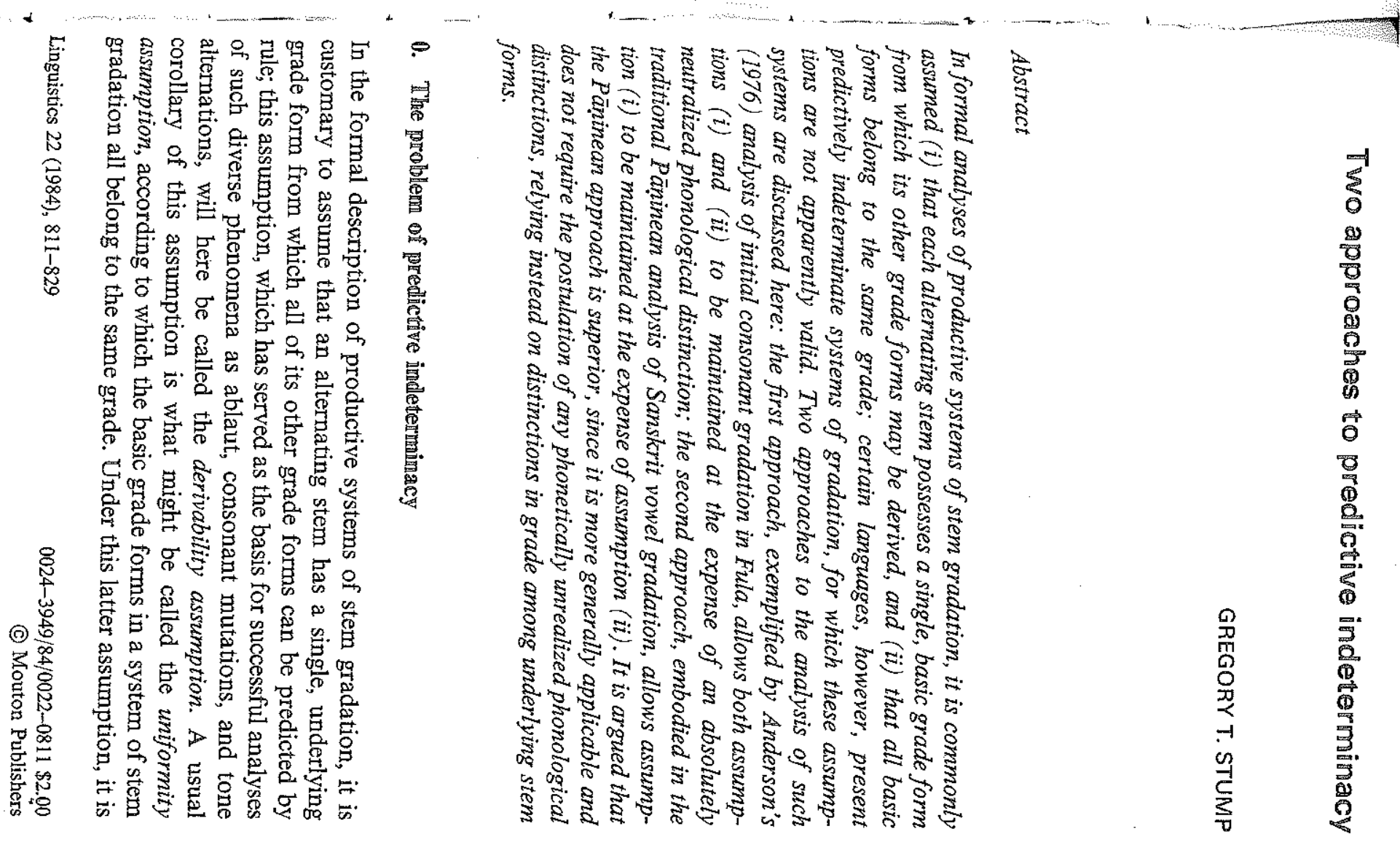




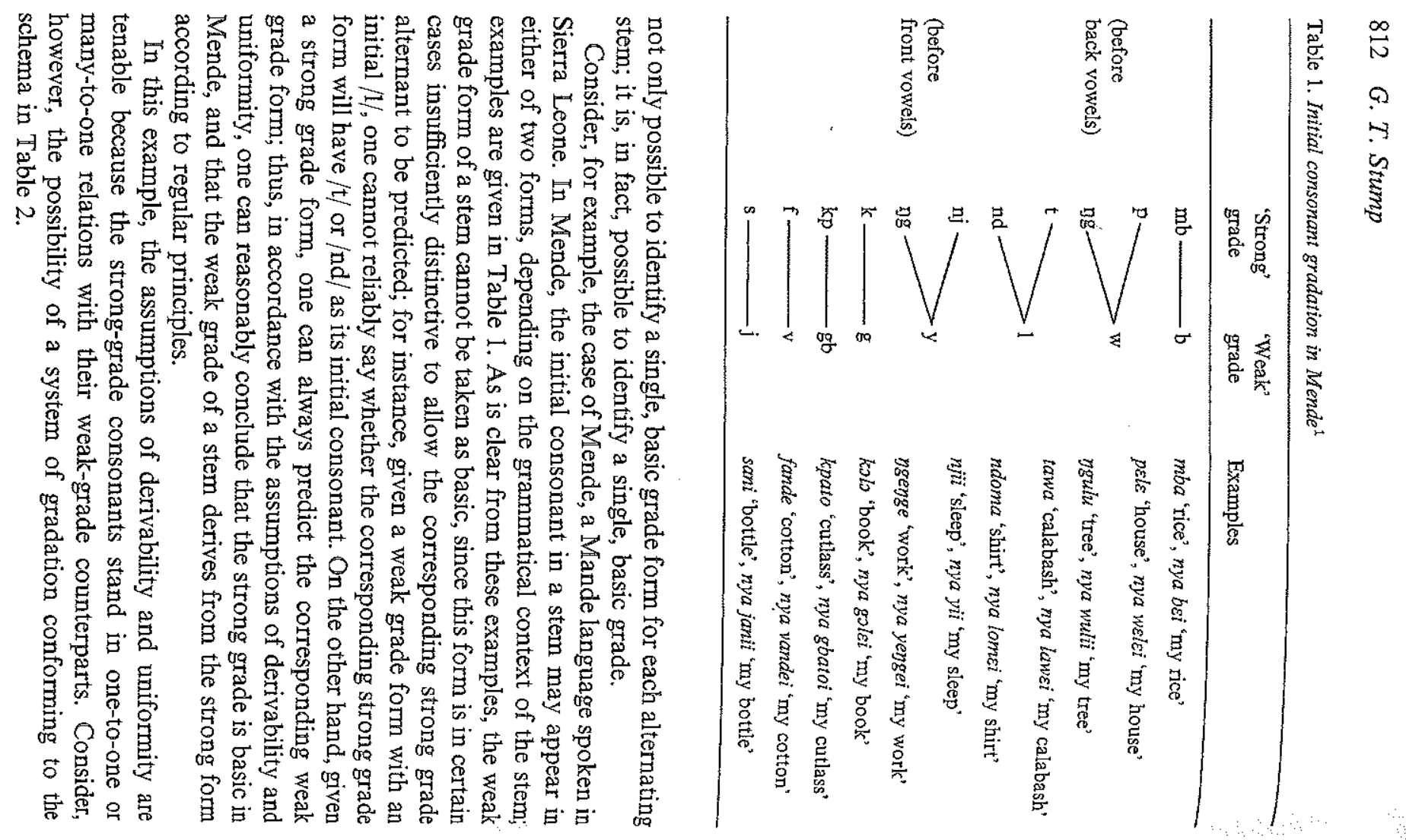

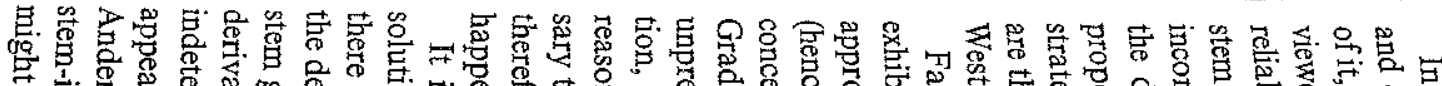

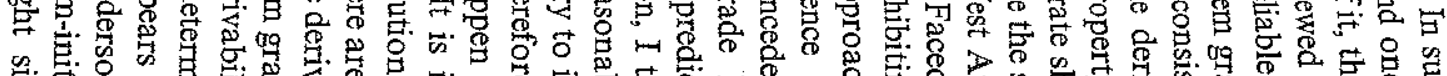

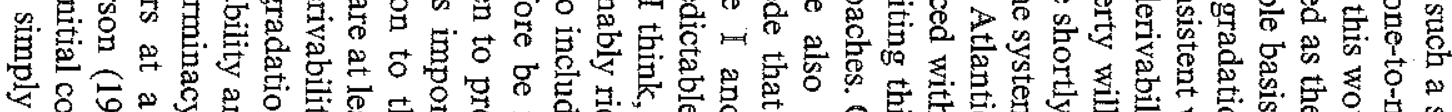

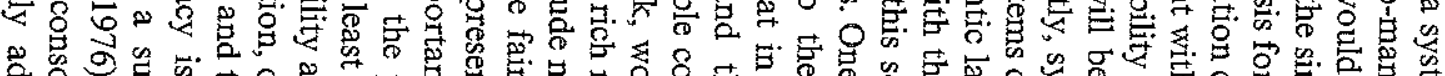

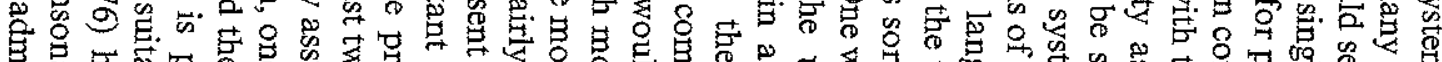

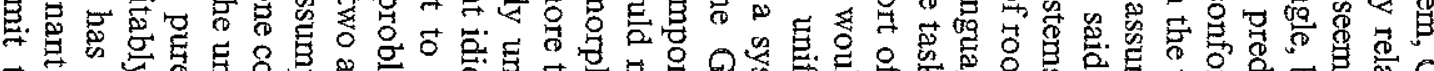

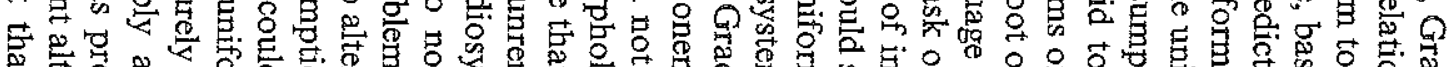

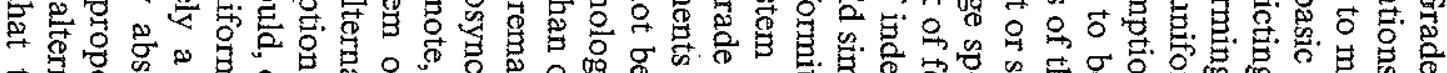

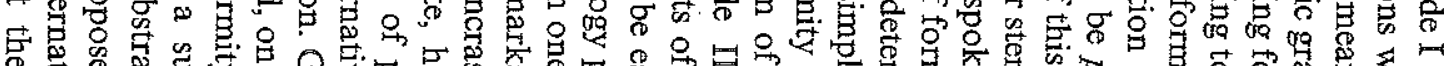

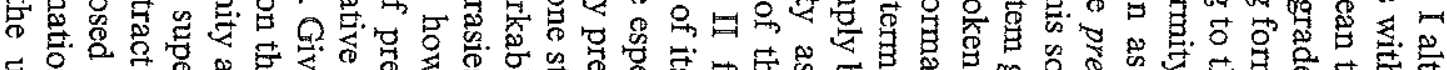

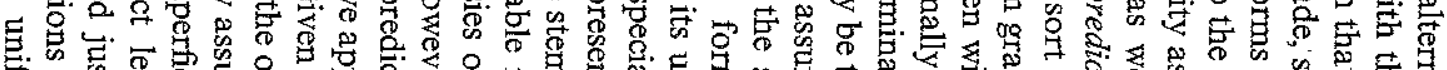

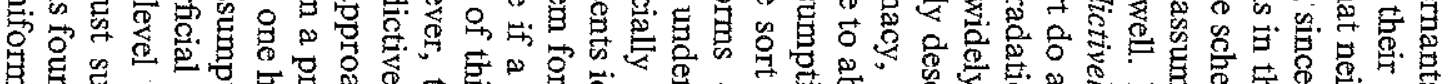

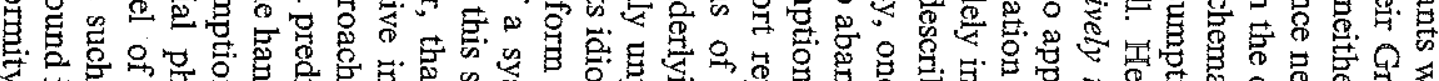

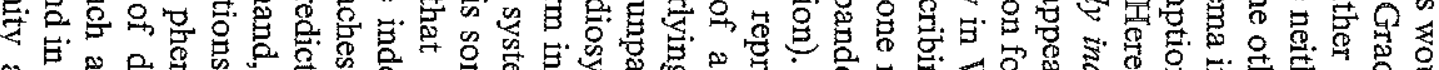

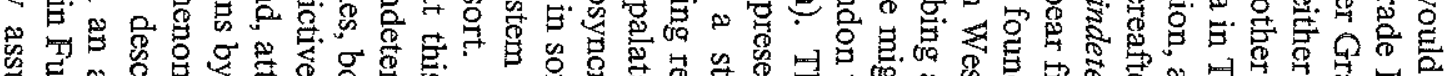

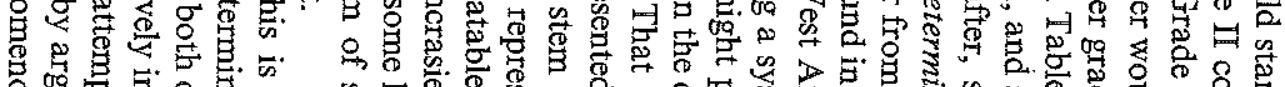

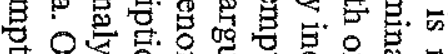

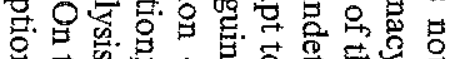

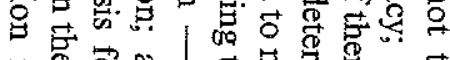

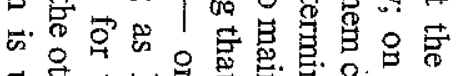

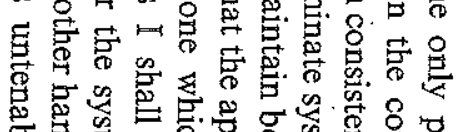

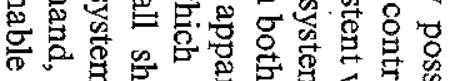

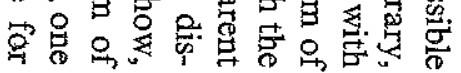

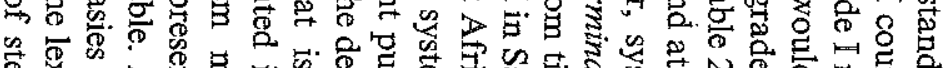

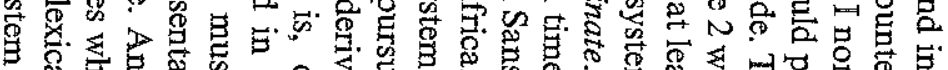

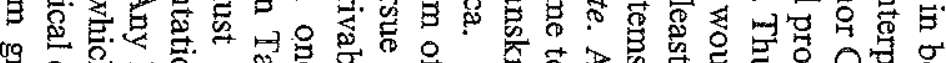

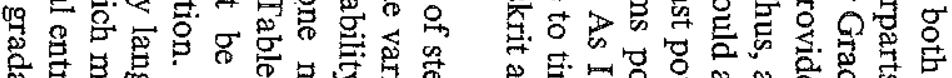

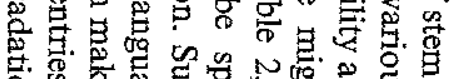

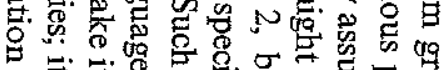

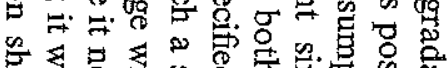

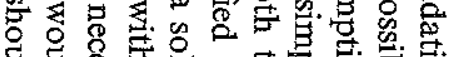

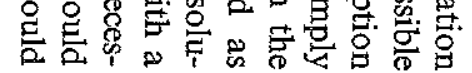

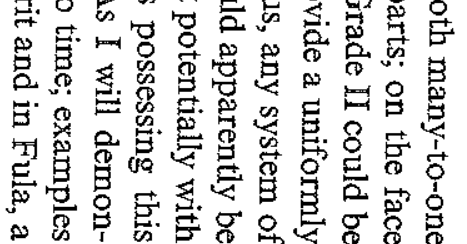

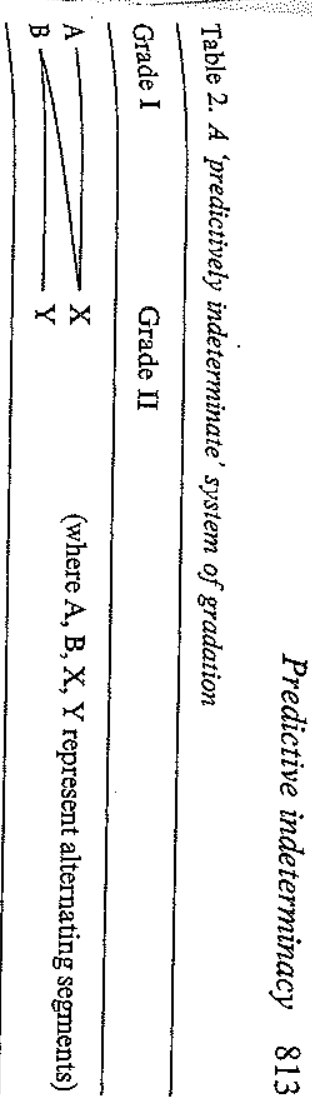



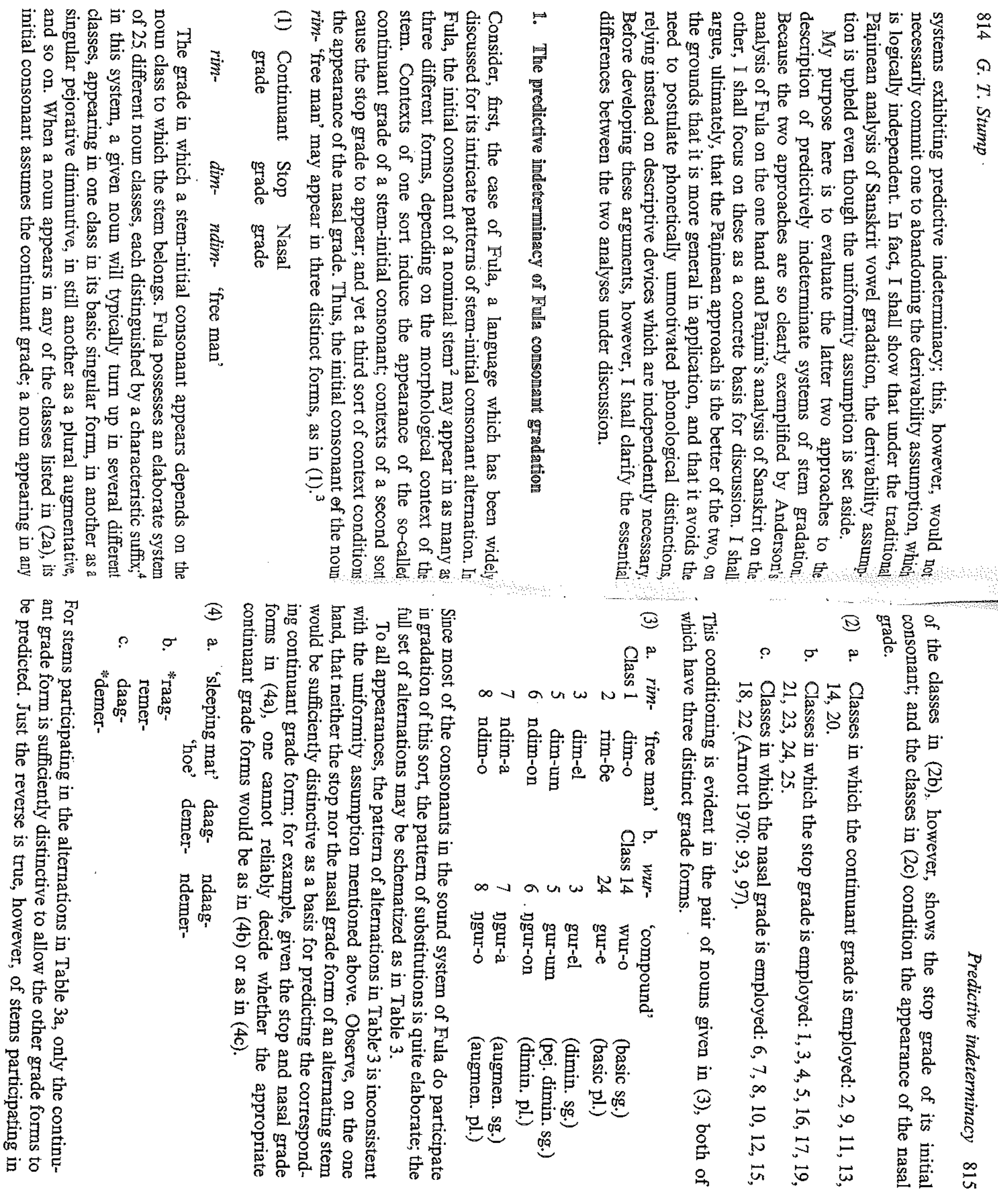


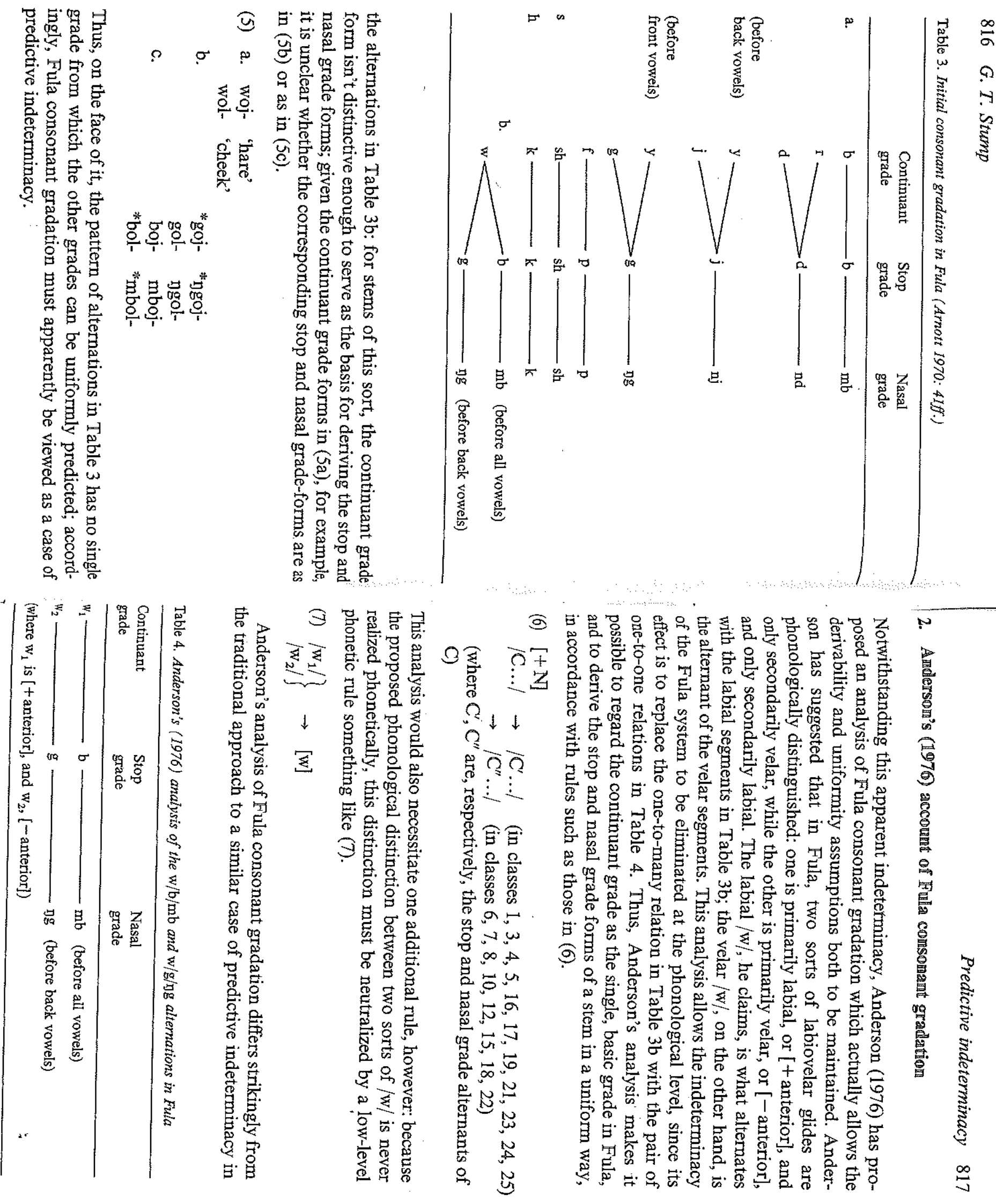



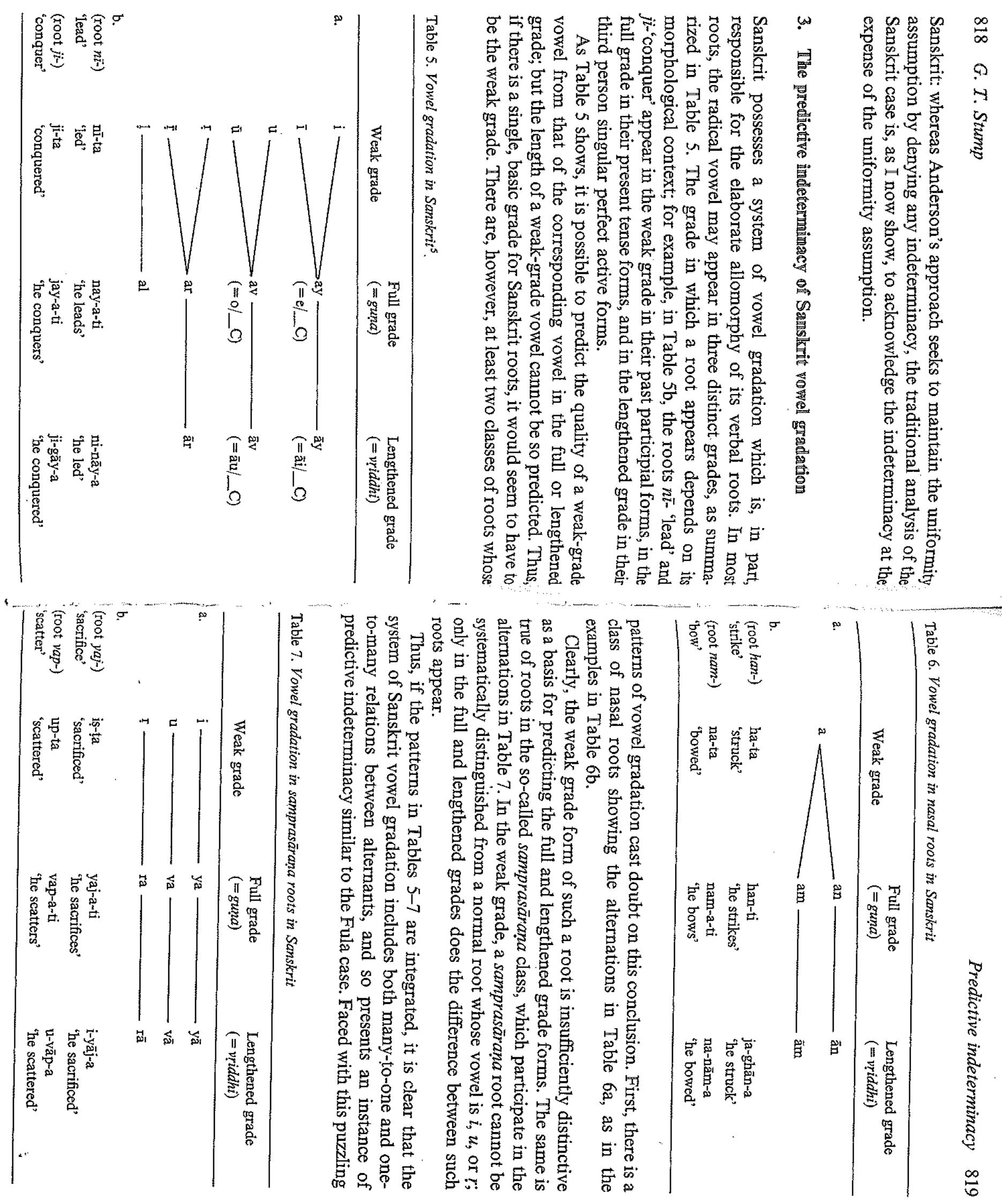
(2) 응 क क

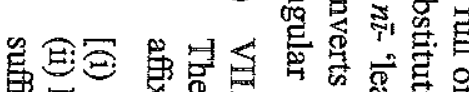

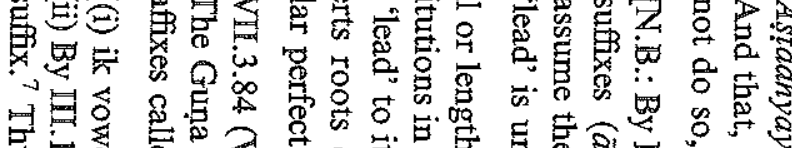

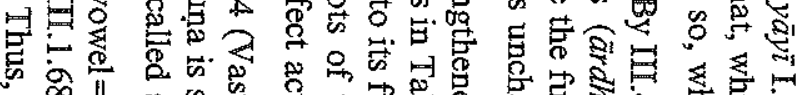

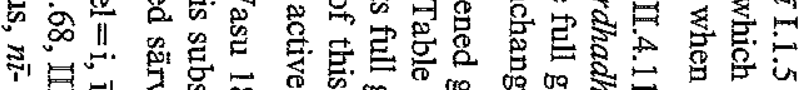

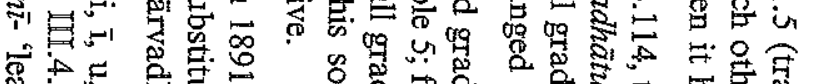

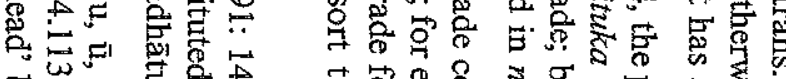

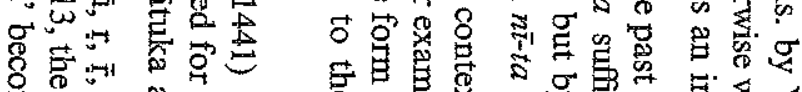

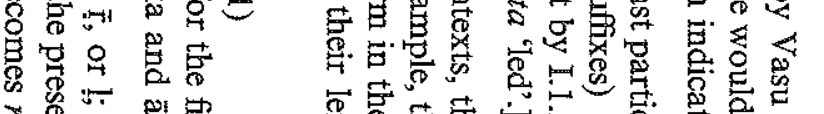

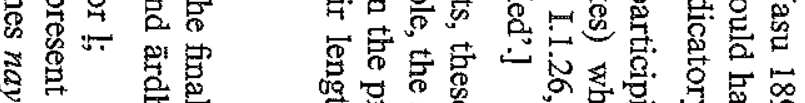

它葛 窟

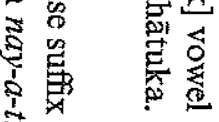

i. 1 年

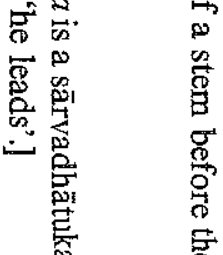

$\infty$

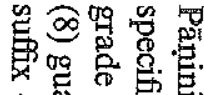
के

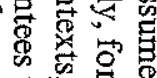

虫官宫

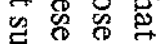
궁형 宫密

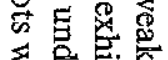

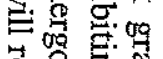
急哭落 兽. \& 坴骂思的.

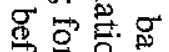

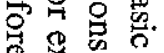

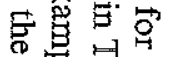

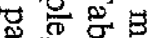
要守 象象 ․ㅡㄹ. 胥. 苟

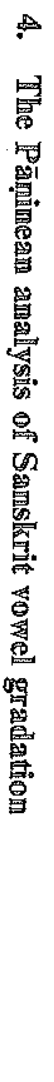

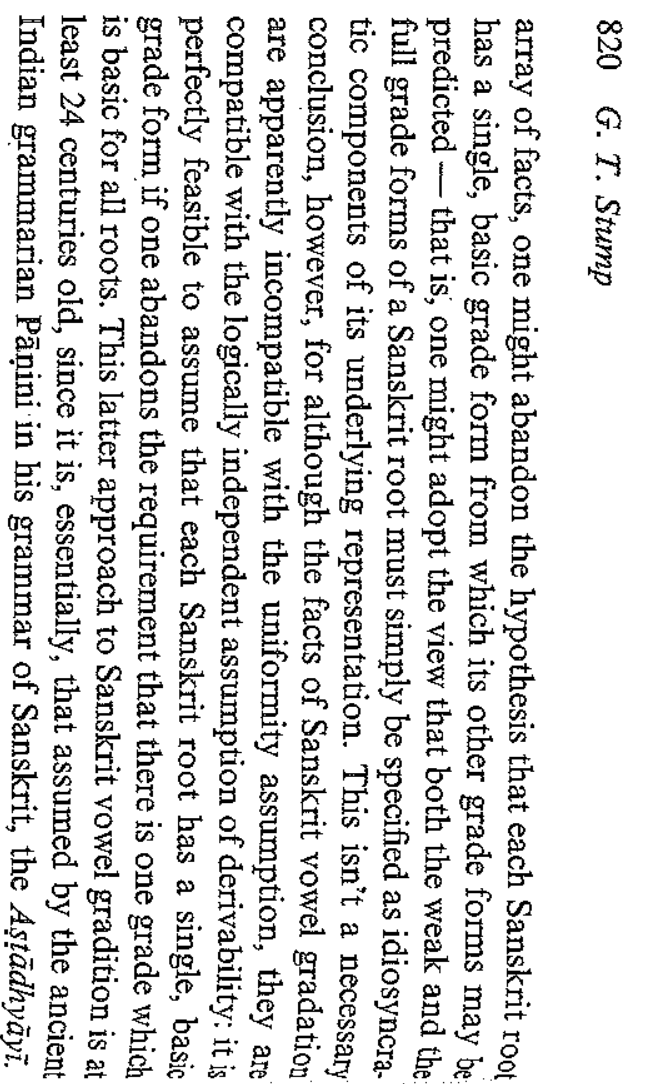

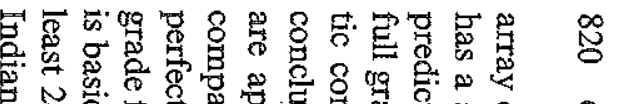

\% 0 \%

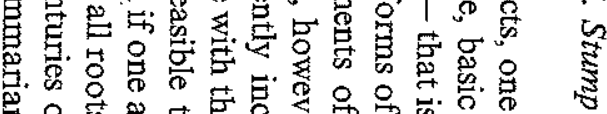

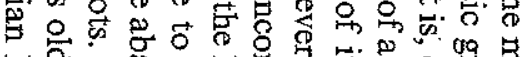

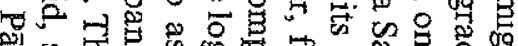
פ. E. 뭉. . क

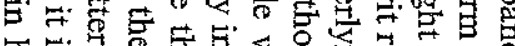

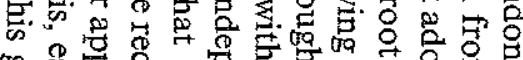

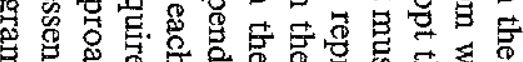

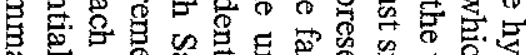

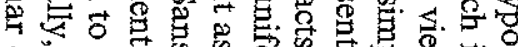

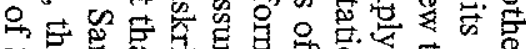

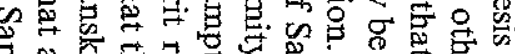

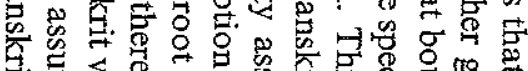

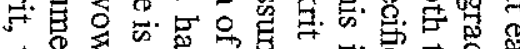

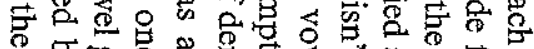

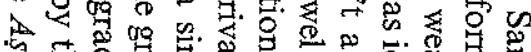

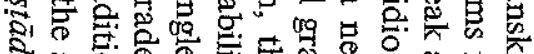

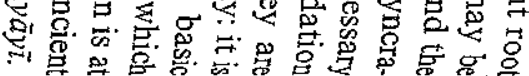

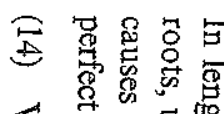

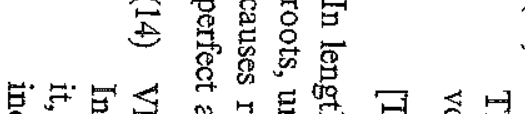

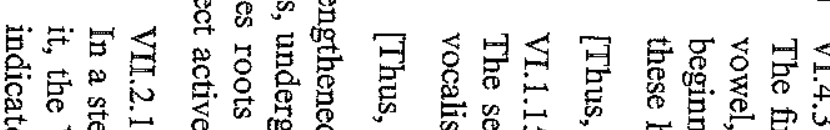

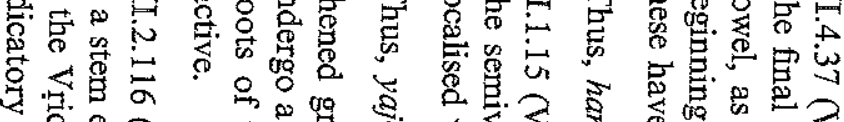

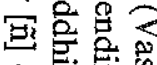

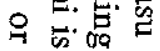
当当客

我要

冚急官

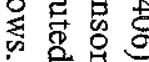

实总

总菅

宓拲

宽悉总 喿 8 虫点. 蛋

के

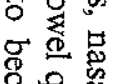

号递

悬总

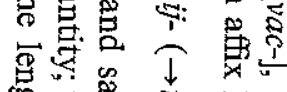

赑

㝵

空

象营

窇宽

哠罗

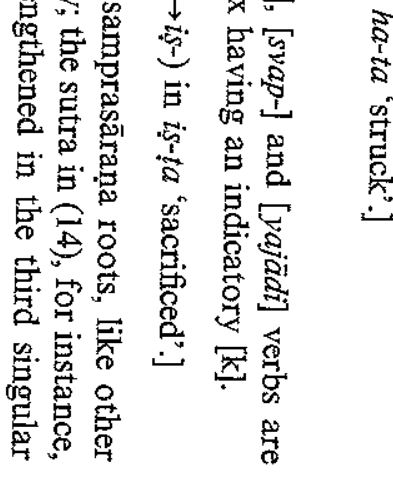

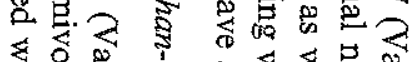

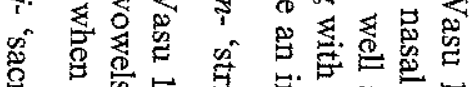

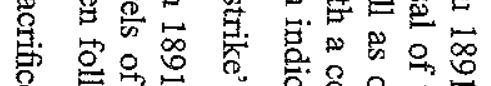

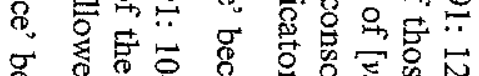

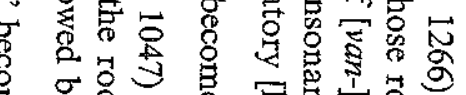

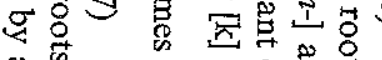

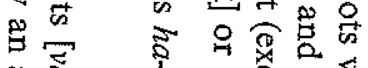

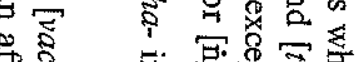
अ 象 8

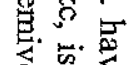
雪 言: 号

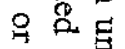
象 遇兽 要

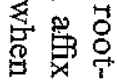

壳若最焉志 象䒿察客 范要骂

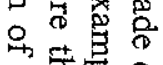

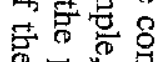

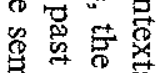

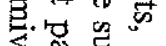

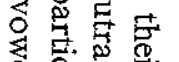
․ 5.

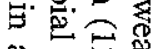
包选 象 常 总乐禺

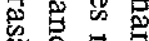
幽吕费 总豆总觉

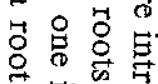
落

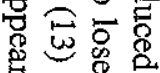

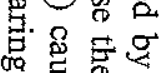

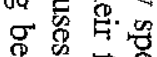

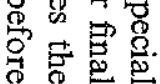

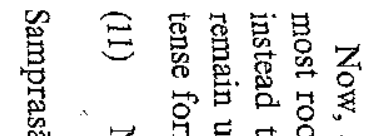

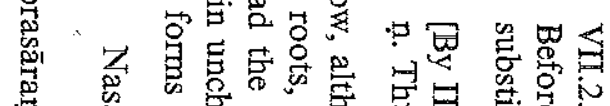

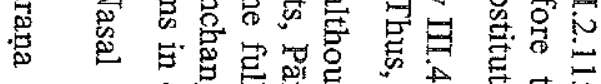

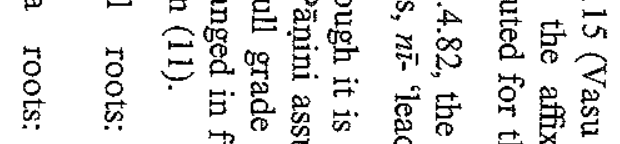

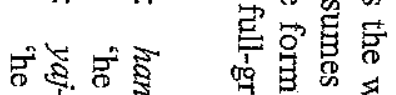

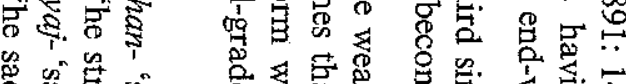

象象象密

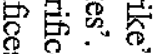

용혈

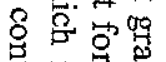

索部言

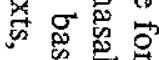

究

究

ㅇํㅇ 路

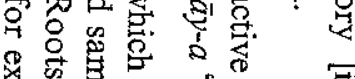

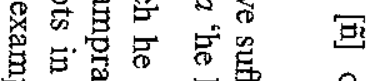

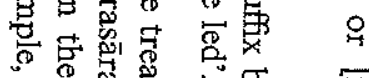

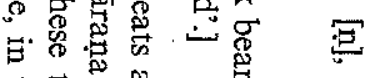

言菦它品

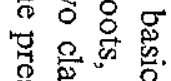

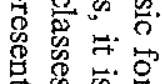

官 


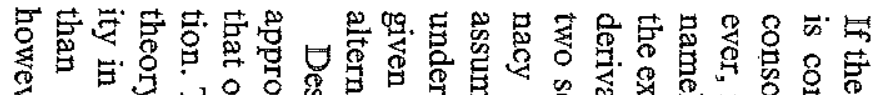

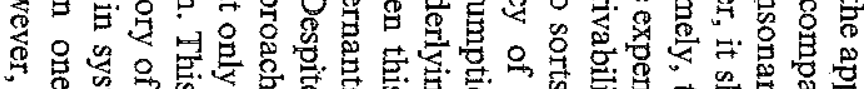

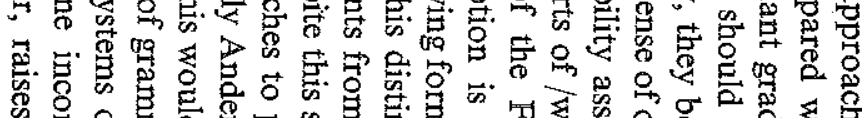

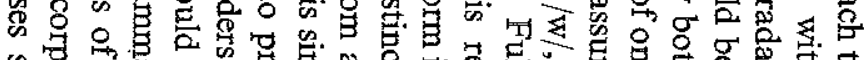

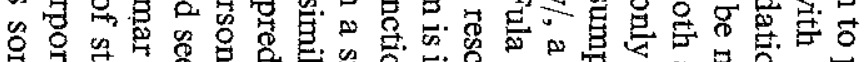

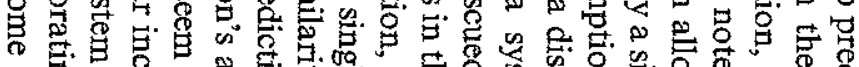

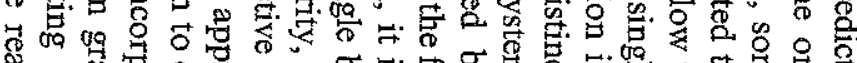

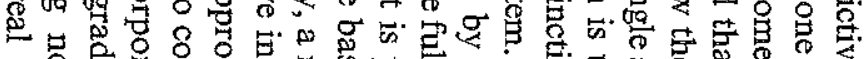

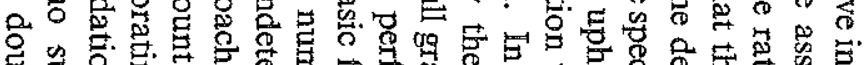

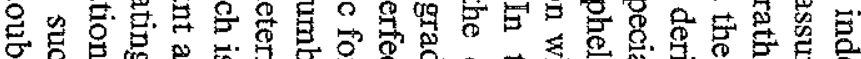

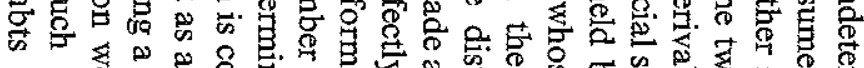

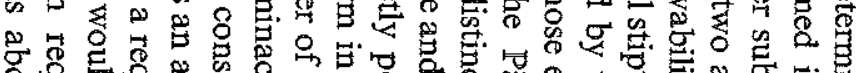

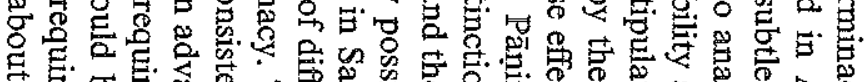

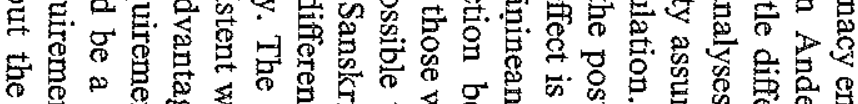

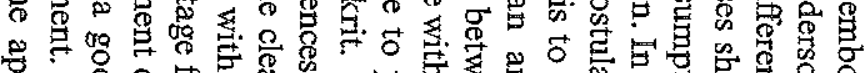

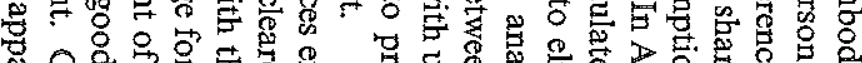

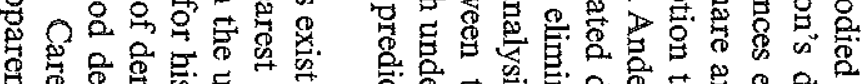

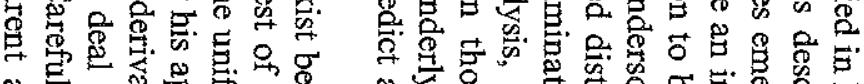

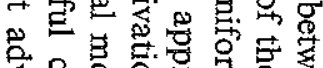

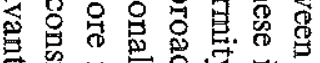

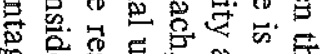

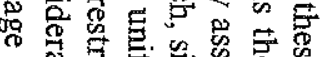

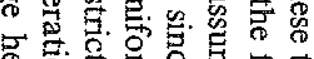

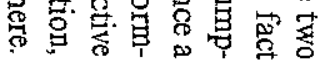

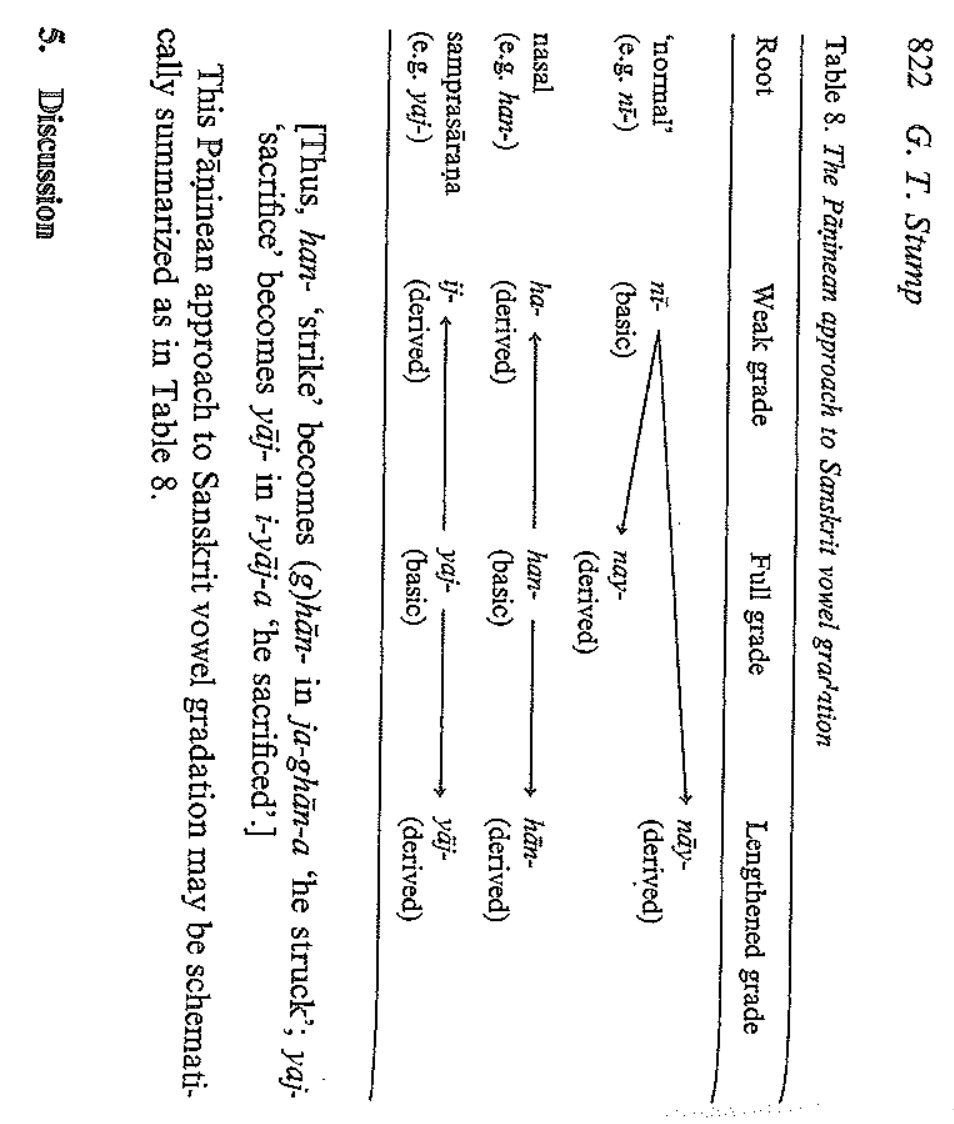

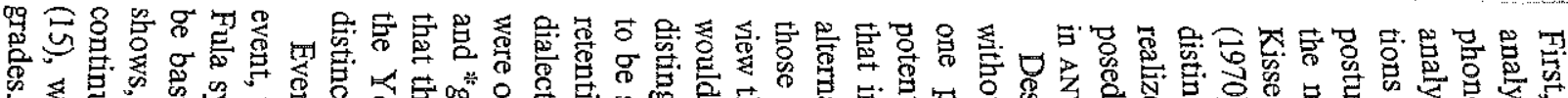

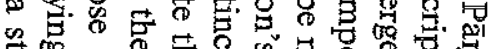
ब舟

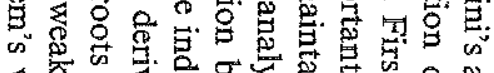

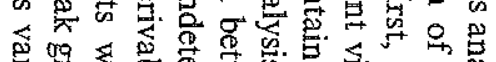

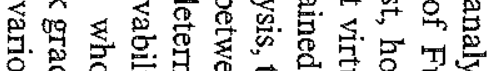

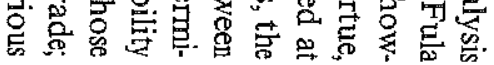

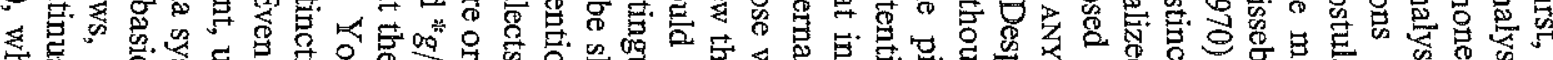

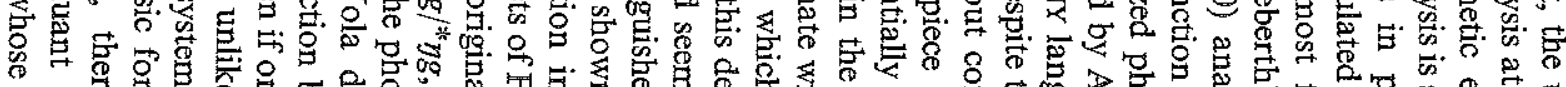

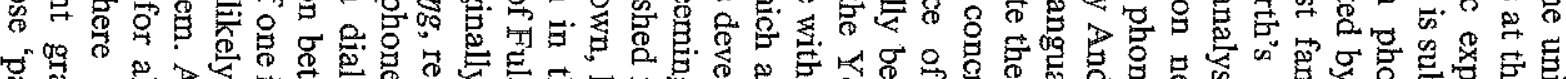

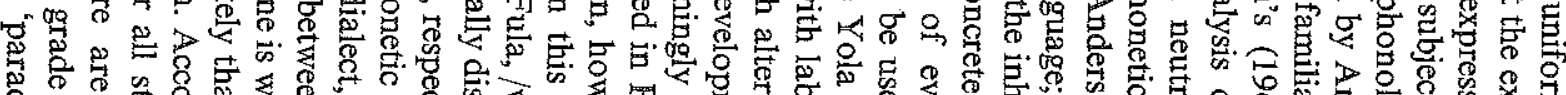

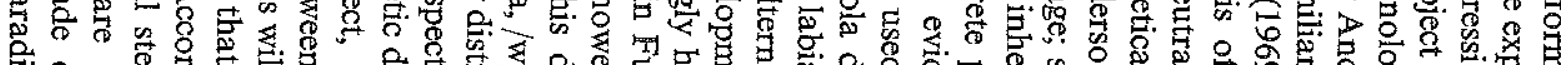

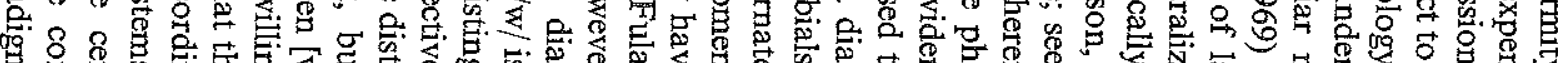

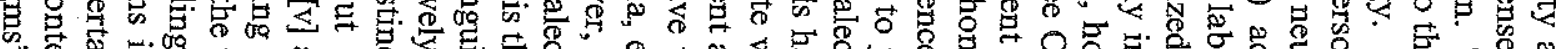

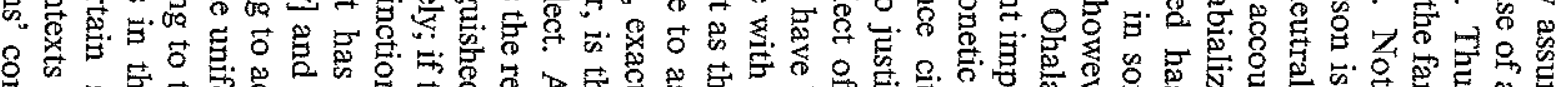

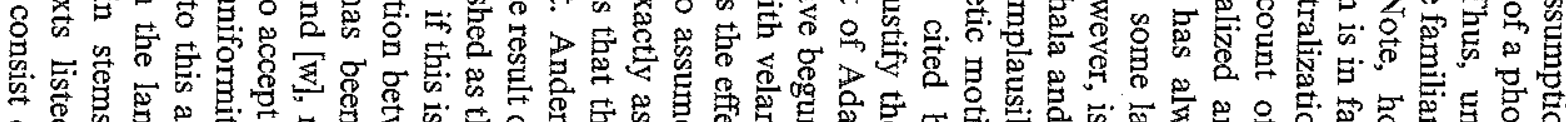

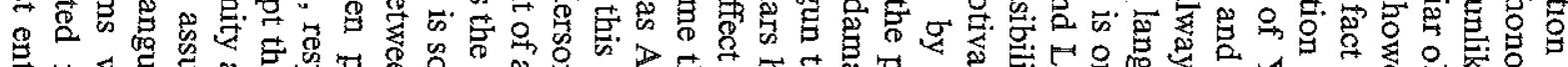

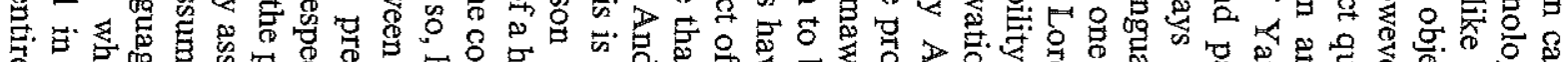

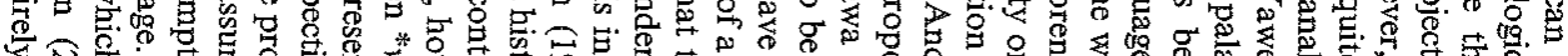
ᄋ

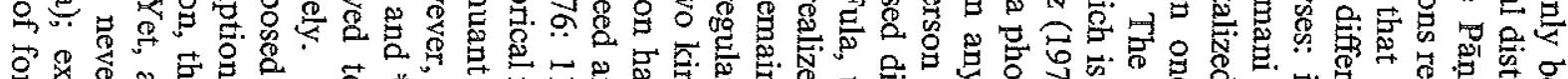

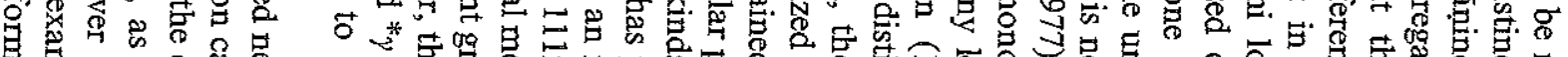

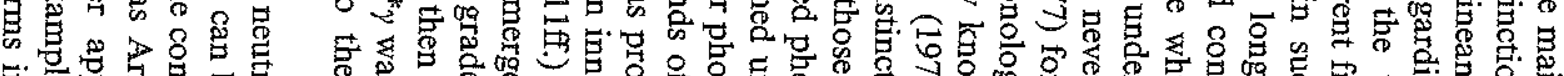

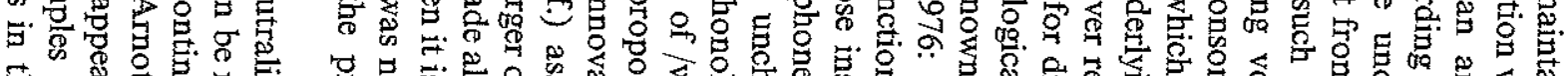

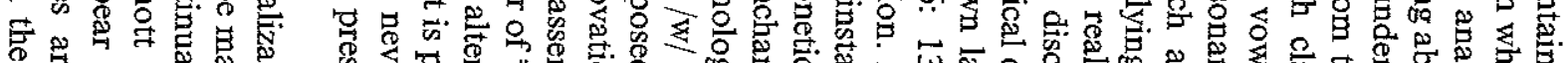

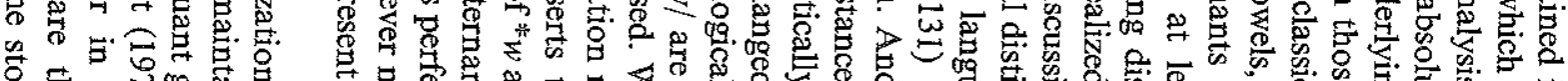

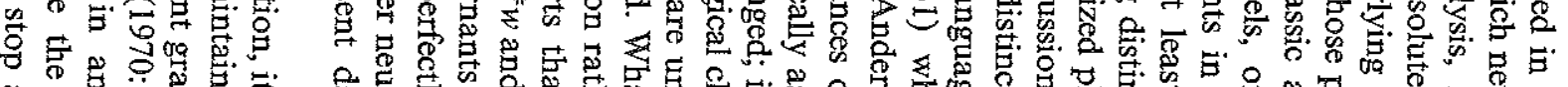

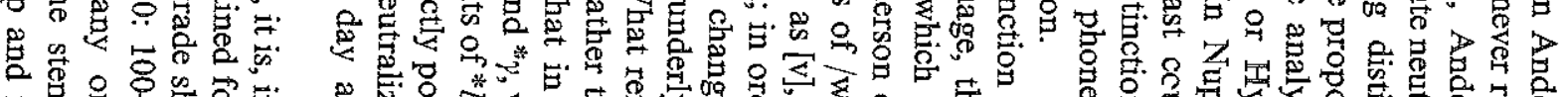

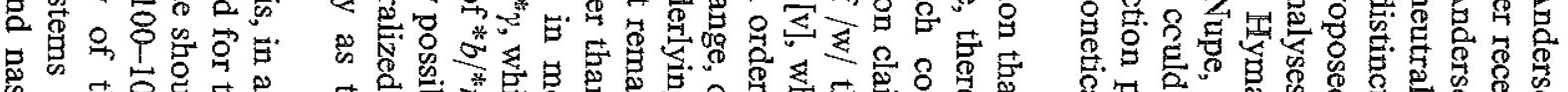

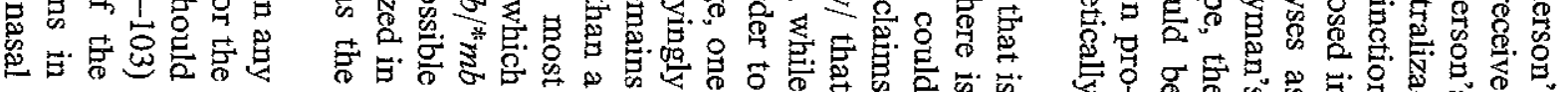




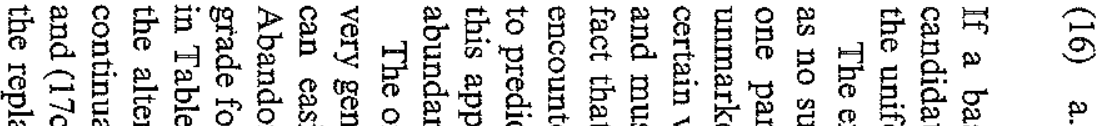

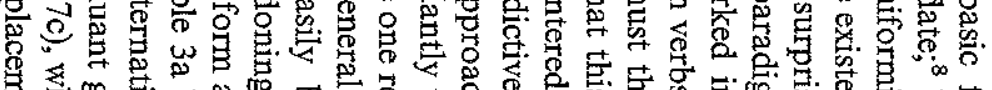

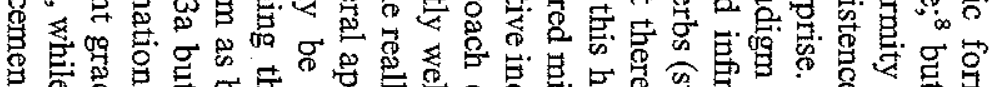

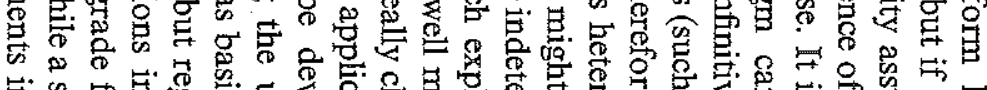

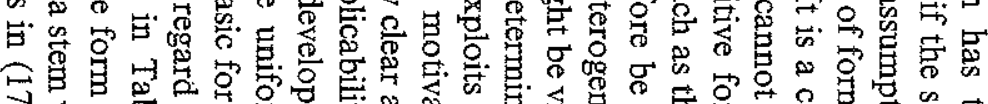

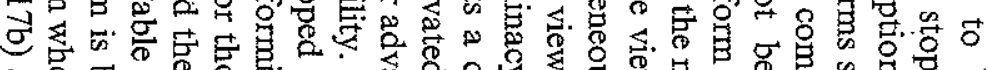

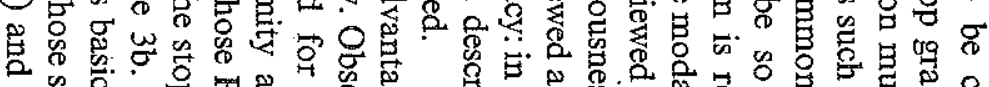

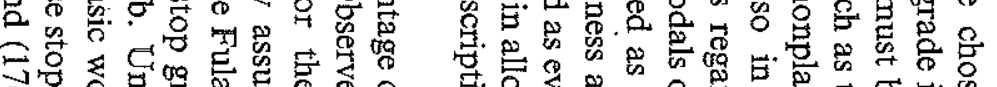

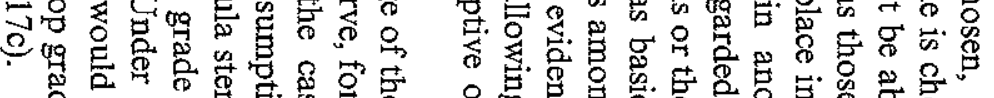

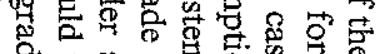

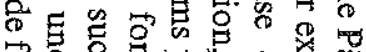

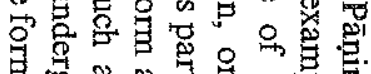

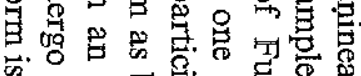

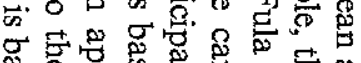

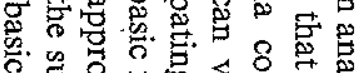

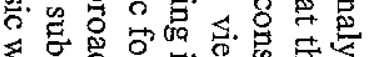

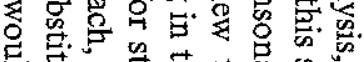

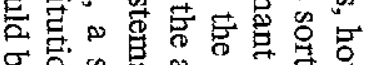

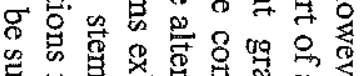

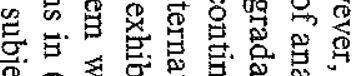

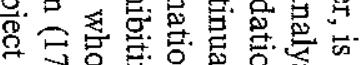

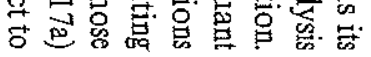

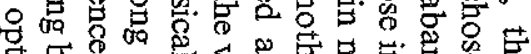

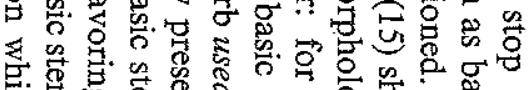

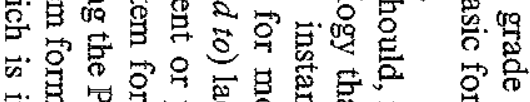

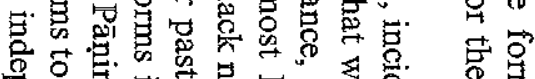

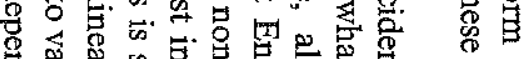

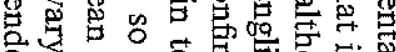

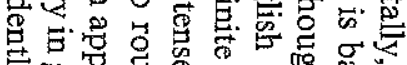

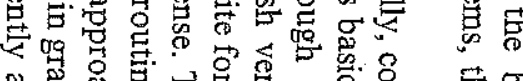

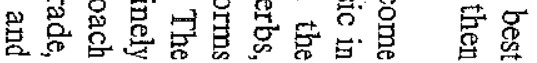

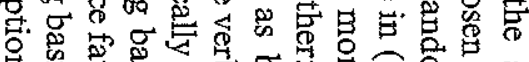

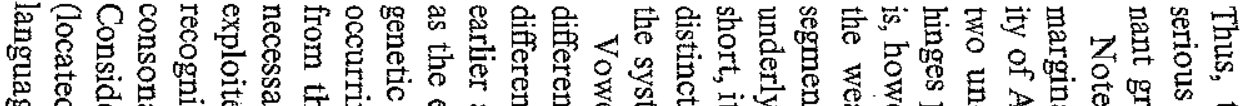

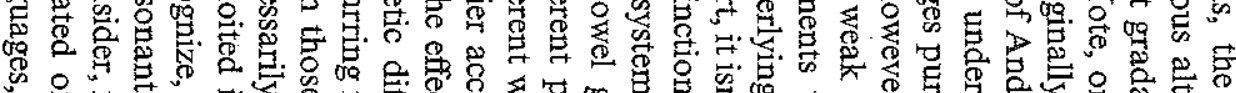

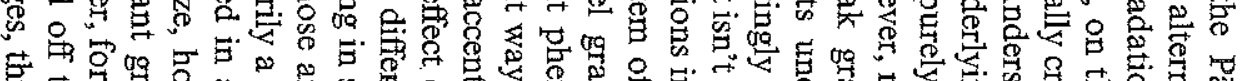

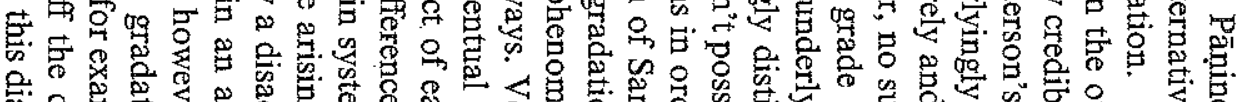

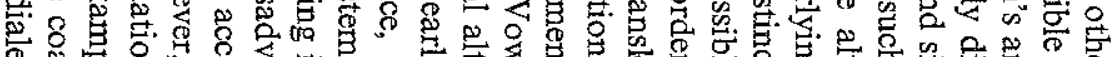

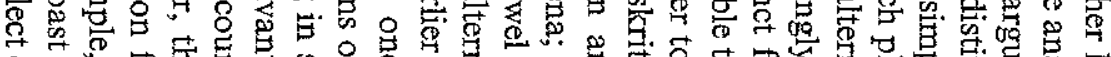

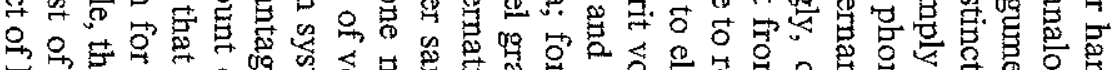

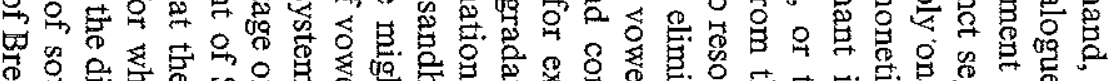

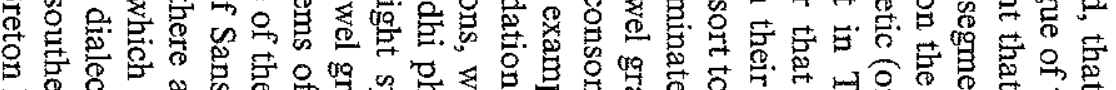

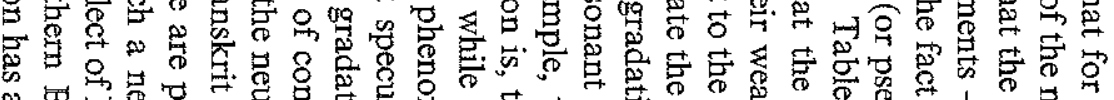

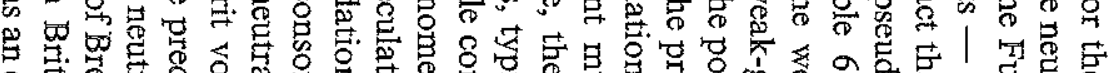

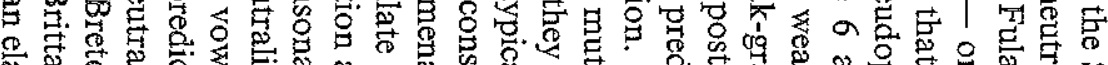

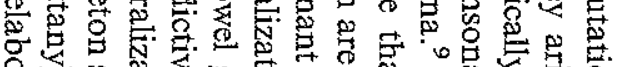

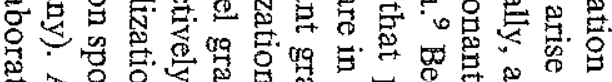

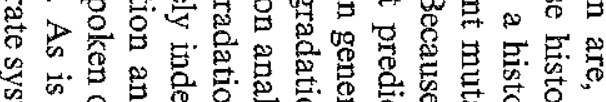

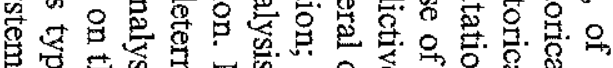

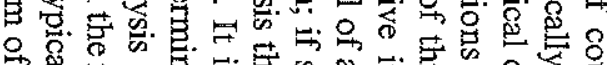

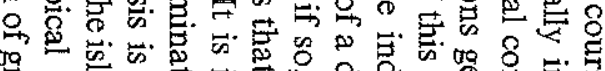

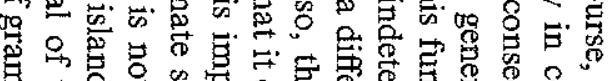

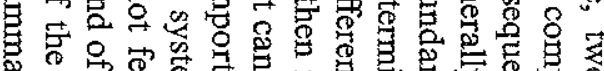

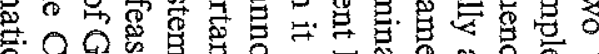

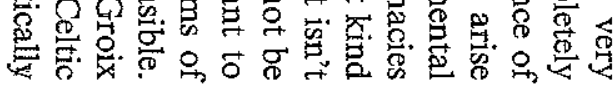

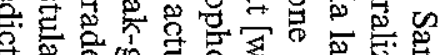

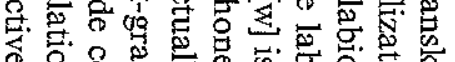

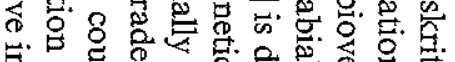

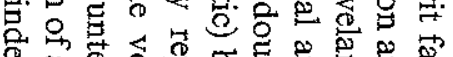

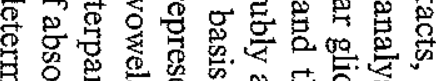

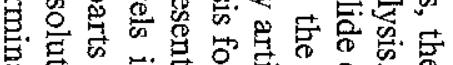

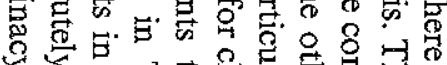

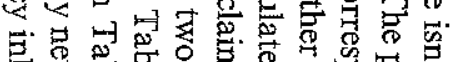

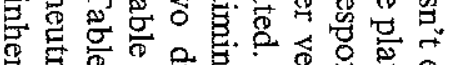

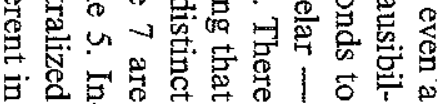

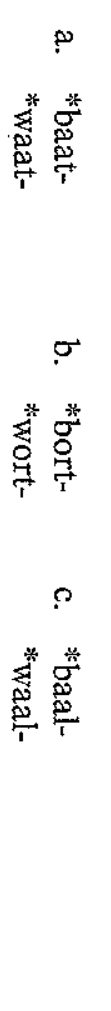

o 8

究

要

कs

苞

萬

苍范

通

兽.

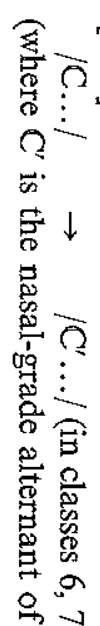
\% के

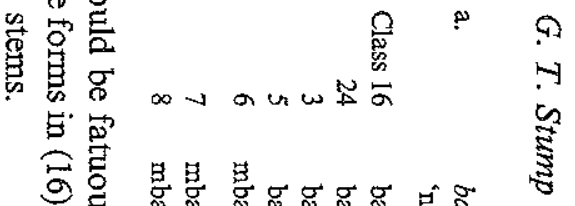

家

营

要

禺星

8

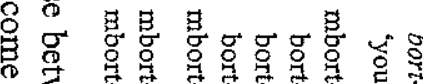

छ

悹宫

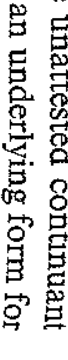

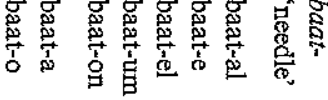
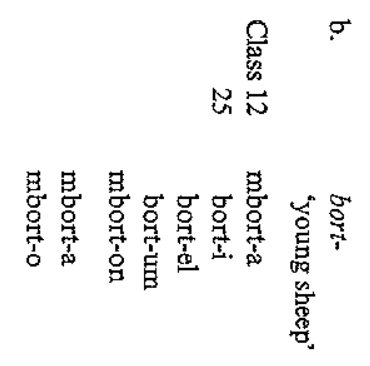

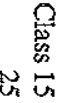

$\frac{2}{8}$

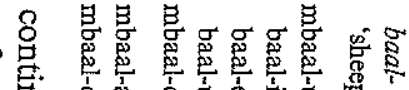

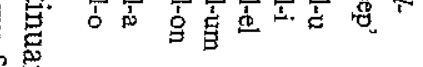

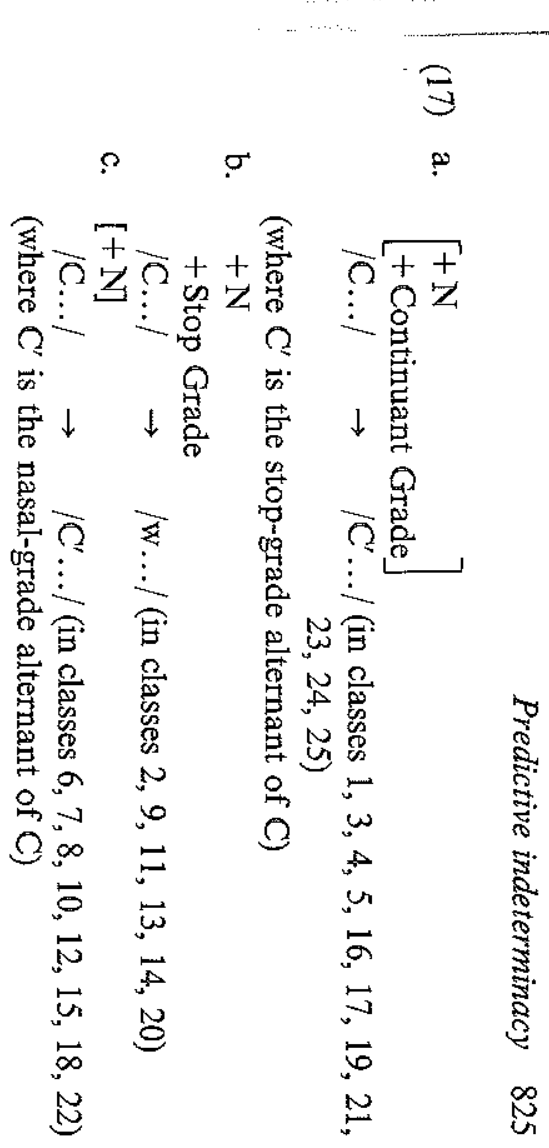




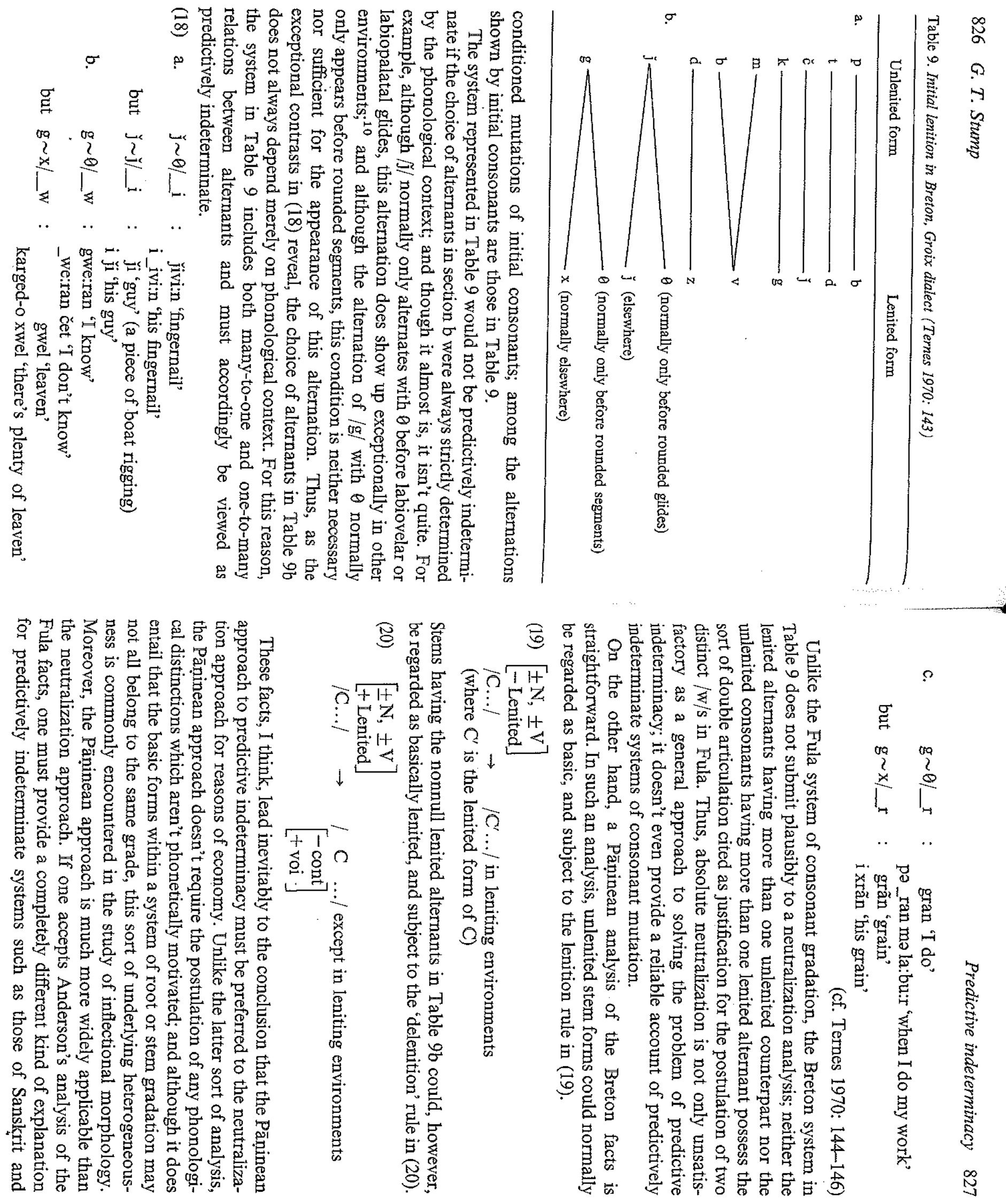



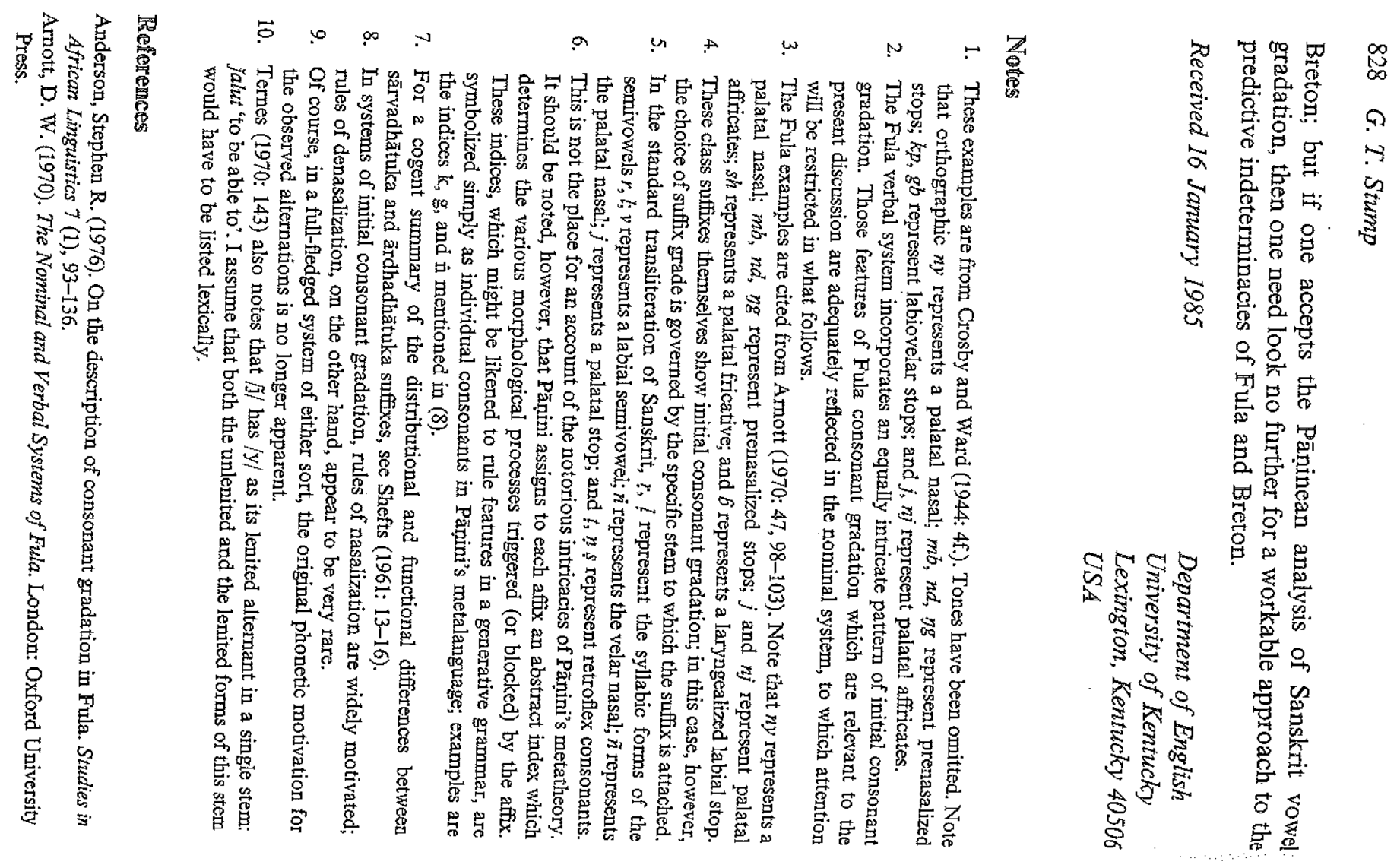

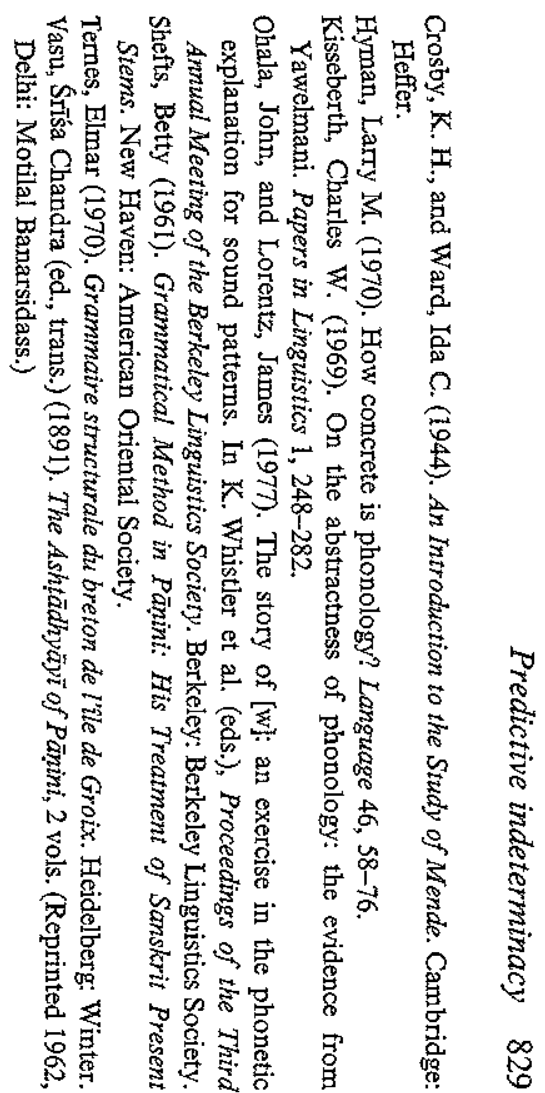

